\title{
Drying of Algae: Analysis of Oedogonium Dehydration Kinetics
}

\author{
Lars Bjorndal \& Ann C. Wilkie \\ University of Florida
}

Faculty Mentor: Ann C. Wilkie, Soil and Water Sciences Department

\begin{abstract}
Algae cultivation has multiple potential applications including biofuel production, wastewater treatment, and carbon capture. However, dewatering and dehydration remain a challenge for commercialization. Research has focused mainly on microalgae, but filamentous algae have recently gained attention due to their larger size and thus relative ease of harvesting. The drying mechanics of filamentous algae has yet to be fully understood and optimized. This study investigated the drying behavior of the filamentous algae Oedogonium at $50^{\circ} \mathrm{C}, 60^{\circ} \mathrm{C}$, and $70^{\circ} \mathrm{C}$. The moisture content of triplicate samples of microalgae and Oedogonium (intact filaments, fractured filaments, and aggregated forms) was measured during drying. Intact Oedogonium filaments were fractured using a food blender. Intact Oedogonium had an average shorter falling-rate phase and higher diffusivity than microalgae at all temperatures, resulting in a $15 \%$, $8.3 \%$, and $11 \%$ faster total average drying time at $50^{\circ} \mathrm{C}, 60^{\circ} \mathrm{C}$, and $70^{\circ} \mathrm{C}$, respectively. Fractured Oedogonium had a shorter falling-rate phase than intact Oedogonium at $50^{\circ} \mathrm{C}$ and $60^{\circ} \mathrm{C}$ where its average total drying time was $18 \%$ and $9 \%$ faster, respectively, but the effect of the fracturing treatment was reduced with increasing temperature and became negligible at $70^{\circ} \mathrm{C}$. Thus, Oedogonium appears to dry more effectively than microalgae and fracturing Oedogonium results in faster dehydration at lower temperatures. These findings could help optimize industrial drying and assist in the commercialization of algae cultivation.
\end{abstract}

Keywords: Oedogonium, microalgae, drying, cell fracturing, algal cultivation, moisture ratio

\section{Introduction}

Algae provide a potentially sustainable alternative to fossil fuels as well as various other applications and have gained increasing attention as the world is transitioning to more sustainable technologies. Through photosynthesis, algae use solar energy to capture the greenhouse gas carbon dioxide $\left(\mathrm{CO}_{2}\right)$ and store potential chemical energy in their cells (Lawton et al., 2014). This process enables algae to be used as a carbon-neutral energy source which could assist in transitioning away from fossil fuel dependency. The high lipid content of some algae species facilitates conversion to biodiesel. Unlike many other biofuel feedstocks, algae do not require arable land to grow. Thus, algae cultivation does not have to compete with resources otherwise used for agriculture (Kraan, 2013). Furthermore, algae absorb nutrients from their surroundings and have potential uses within wastewater treatment (Cole et al., 2016; Edmundson 
\& Wilkie, 2013; Piotrowski et al., 2020). Algae biomass can also be used as feedstock for biogas production in anaerobic digesters (Wilkie, 2008; Wilkie et al., 2011). Because of this versatility, research is being conducted on combining algae cultivation with industrial processes. For example, studies have evaluated the integration of algae production with wastewater treatment and capturing of $\mathrm{CO}_{2}$ emissions from fossil fuel-based energy production and industrial processes (Cole et al., 2014; Cole et al., 2016; Edmundson \& Wilkie, 2013; Lincoln et al., 1996; O’Connell \& Wilkie, 2018; Wilkie \& Mulbry, 2002).

This broad array of applications has resulted in a growing interest in commercialization; however, algae have a large amount of internally bound moisture and the high costs of dewatering and drying remain a significant obstacle for large-scale adoptation. Biomass recovery and drying are energy-intensive processes that account for up to $70-75 \%$ of total processing costs (Show et al., 2013). Thus, there are few large-scale algae cultivation facilities and the main commercial applications are still smaller niche industries like human and animal nutrition and cosmetics (Spolaore et al., 2006; Wilkie et al., 2011).

Although most algae research to date has been focused on microalgae, interest in filamentous macroalgae such as Oedogonium has increased (Grayburn et al., 2013; Zhang et al, 2016). Compared to microalgae, which typically consist of one or a few 2-30 $\mu \mathrm{m}$ cells, Oedogonium grows in long filaments which occasionally self-entangle to create spherically aggregated forms (Molina Grima et al., 2003). Filamentous algae can be easily harvested using a net, thus drastically reducing the resources needed for biomass recovery, which constitutes $20-30 \%$ of total production costs (Gudin \& Thepenier, 1986). Oedogonium has also been identified as a viable alga for biofuel production and carbon capturing (O'Connell \& Wilkie, 2018; Zhang et al., 2016).

Since drying constitutes the major part of algae cultivation costs, improved knowledge and optimization of this process is essential for economic viability. This study specifically looks at the drying mechanics for thin-layer drying where diffusion has been documented as the dominant mechanism of moisture removal for fruits and vegetables (Akpinar, 2006; Guiné et al., 2011; Onwude et al., 2016) and Oedogonium (Hammond et al., 2018). Hammond et al. (2018) successfully modeled the falling-rate drying pattern of Oedogonium and established effective sample diffusivity using Sherwood's analytical solution of Fick's Second Law of Diffusion 
(Sherwood, 1932). Such modeling gives improved analytical insight and can help optimize the drying process, thereby increasing efficiency and decreasing operational costs.

Based on the hypothesis that the filamentous nature of Oedogonium would result in faster drying, this study investigated the comparative drying of Oedogonium and the microalgae Scenedesmus and Ankistrodesmus. Further optimization of Oedogonium drying was also explored through the hypotheses that (1) fracturing Oedogonium filaments into several smaller pieces would help to release moisture held inside the cells and (2) that the aggregated forms would provide a larger surface area for evaporation. Moreover, the temperature dependence of the comparative and optimized drying was investigated at $50^{\circ} \mathrm{C}, 60^{\circ} \mathrm{C}$, and $70^{\circ} \mathrm{C}$.

\section{Incubation and Fertilization}

\section{Materials and Methods}

Oedogonium cultures were grown outside in two 100-L open raceway ponds at the Bioenergy and Sustainable Technology Laboratory, Soil and Water Sciences Department, University of Florida in Gainesville, Florida, and were fertilized weekly with $40 \mathrm{mg} / \mathrm{L}$ of Miracle-Gro (N-P-K: 30-10-10). Each pond was inoculated using $15 \mathrm{~L}$ of lab reserve cultures propagated from a locally isolated strain of Oedogonium. The water levels were then gradually increased to $100 \mathrm{~L}$ as the culture density increased.

Oedogonium samples were a mixture of the two pond cultures and were collected by siphoning and directing the water from the ponds through a pool skimmer to collect an algae slurry, as seen in Figure 1. Spherically aggregated forms were manually removed from this slurry, with some additional samples being collected from the ponds. These aggregated forms were 5 to $20 \mathrm{~mm}$ in diameter with the majority being around $7 \mathrm{~mm}$.

For the comparative drying study, a biculture of local strains of the microalgae Scenedesmus and Ankistrodesmus was also collected. This established biculture was maintained in a 1000-L open outdoor raceway pond and received the same weekly fertilization as the Oedogonium cultures $(40 \mathrm{mg} / \mathrm{L})$. To collect the microalgae, the pond paddlewheel was turned off for 24 hours to allow algae to settle at the bottom of the pond before they were was collected using a small pool skimmer. 


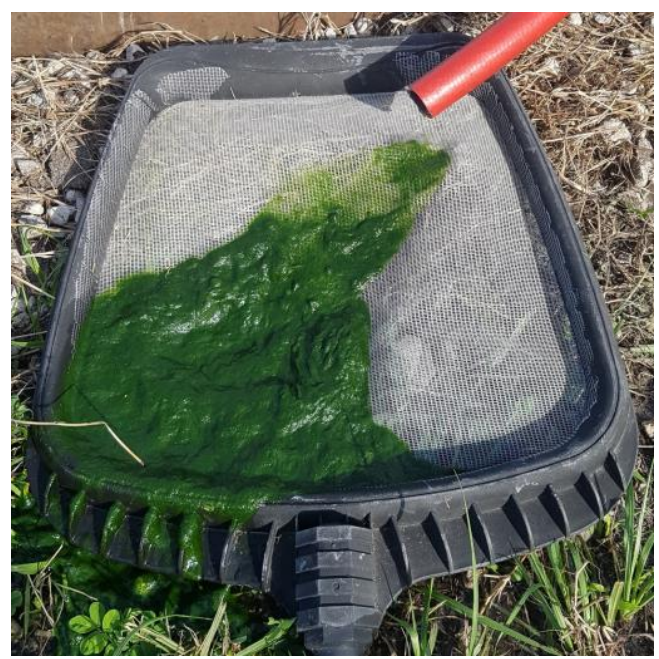

Figure 1. Oedogonium Collection.

\section{Dewatering and Drying}

Before dewatering, half of the collected intact Oedogonium was fractured using a food blender at high intensity for 2 minutes. Then, a measuring spoon was used to extract approximately $15 \mathrm{~mL}$ of algae slurry from the respective samples for microalgae, intact Oedogonium, and fractured Oedogonium. The aggregated forms were also placed in the same measuring spoon until they filled the same volume. To remove surface moisture before drying, the $15 \mathrm{~mL}$ of slurry or aggregated forms were then poured onto 10 layers of $9 \mathrm{~cm}$ by $9 \mathrm{~cm}$ blotting paper (Figure 2a) and pressed for 20 seconds using a $1 \mathrm{~kg}$ weight (Figure 2b), while placed on top of a Petri dish for even distribution. Thus, excess water from the algae was transferred to the paper towel (Figure 2c) leaving a dewatered sample, as seen in Figure 2d.

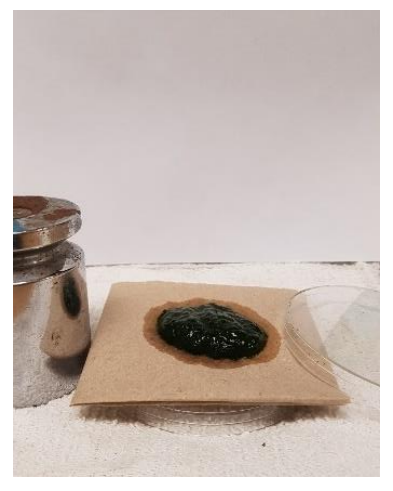

(a)

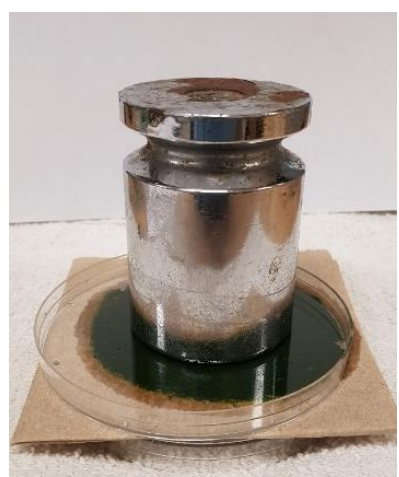

(b)

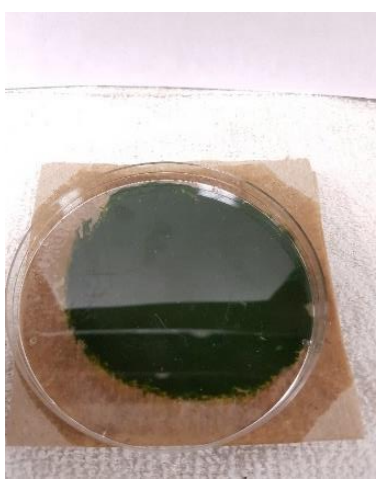

(c)

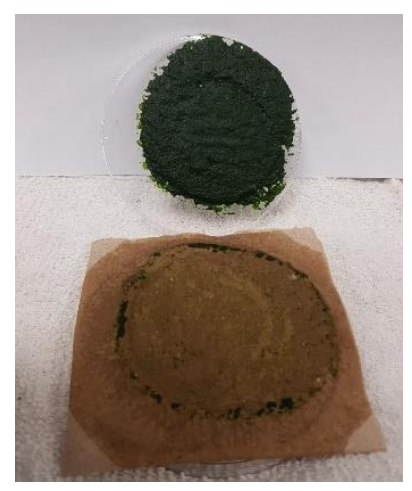

(d)

Figure 2. Excess Water Removal by Blotting. 
For the drying experiments, $6.0 \mathrm{~g}$ samples of dewatered algae were placed in pre-weighed $200 \mathrm{~mL}$ aluminum dishes (Fisher Scientific, Waltham, MA) and evenly spread across the bottom of the dish to a measured thickness of $2 \mathrm{~mm}$. The aggregated forms were simply placed in the dishes to achieve the appropriate weight. A triplicate of each of the four algae groups was prepared immediately before each experiment. After this preparation, the dishes were dried in a laboratory drying oven.

Three separate experiments were carried out where the Oedogonium (intact, fractured, and aggregated forms) and the microalgae control were dried at $50^{\circ} \mathrm{C}, 60^{\circ} \mathrm{C}$, and $70^{\circ} \mathrm{C}$. During drying, each aluminum dish was taken out of the oven and weighed every 15 minutes. These measurements were continued until there was no longer any change in mass. Finally, when the dry weight of each sample was determined, it was used to find the initial moisture and total solids content (TS) of the algae before drying, after dewatering.

\section{Data Processing}

The weight of the algae samples before and during drying was found by subtracting the weight of the empty aluminum dishes from the measured weight of the dishes and algae (APHA, 2012). The moisture ratio (MR), which is a dimensionless ratio commonly used for drying analysis (Onwude et al., 2016), was then calculated for each data point according to Eq (1). MC was the total moisture content of the algae at the time of measuring, $M C_{e}$ the equilibrium moisture content reached after drying, and $M C_{o}$ the original moisture content when drying started. This data was used to plot the MR over time and the change over time of MR was calculated to express drying rates.

$$
M R=\frac{M C-M C_{e}}{M C_{o}-M C_{e}}
$$

Fick's Second Law of Diffusion is described by Eq (2) where $\mathrm{D}_{\mathrm{e}}$ stands for effective diffusivity and $\mathrm{M}$ is moisture content. Similar to Hammond et al. (2018), this study used Sherwood's analytical series solution, Eq (3), to solve Eq (2) (Sherwood, 1932). In Eq (3), L is the infinite sample thickness and $t$ is time. However, this approach is only well suited for modeling drying during a falling-rate phase and $\mathrm{Eq}(1)$ and $\mathrm{Eq}$ (3) were therefore adapted. For $\mathrm{Eq}(1)$, a new $M R$ was established for each sample by setting $M C_{o}$ equal to $M C$ at the transition from the constant-rate to the falling-rate phase and, for Eq (3), $t$ was set to zero at the transition 
point. Then, the first eleven terms of Eq (3) were used to model the moisture ratio over time of each algae group during drying, and Excel's solver function was used to find the effective diffusivity constant, $D_{e}$, by reducing the residual sum of squares (RSS) between the formula predictions and the average MR data for each group and temperature.

$$
\begin{gathered}
\frac{\partial M}{\partial t}=D_{e} \nabla^{2} M \\
M R=\frac{8}{\pi^{2}} \sum_{n=0}^{\infty} \frac{1}{(2 n+1)^{2}} \exp \left(-(2 n+1)^{2} \frac{\pi^{2} D_{e} t}{4 L^{2}}\right)
\end{gathered}
$$

Finally, an Excel function for multivariable linear regression and ANOVA analysis was used to assess the effect of the fracturing treatment during the constant phase of drying by using the MR as a dependent variable and the sample group, time, and temperatures as independent variables.

\section{Results}

\section{Total Solids Concentration}

After drying all samples and calculating their total solids concentration (TS), it was found that the microalgae had an initially larger TS after dewatering (Table 1). The microalgae had an average TS of $12.18 \%$ while intact Oedogonium filaments had an average TS of 9.13\%. Consequently, the microalgae contained less water than the Oedogonium samples before the drying started. 
Table 1. Initial Total Solids (TS) Concentration of Samples and Standard Deviation (SD) after Dewatering.

\begin{tabular}{|c|c|c|c|c|c|c|c|}
\hline Algae Group & $\begin{array}{c}\text { TS } \\
\text { Sample } 1\end{array}$ & $\begin{array}{c}\text { TS } \\
\text { Sample } 2\end{array}$ & $\begin{array}{c}\text { TS } \\
\text { Sample } 3\end{array}$ & $\begin{array}{c}\text { TS } \\
\text { Average }\end{array}$ & SD & $\begin{array}{c}\text { Group } \\
\text { Average }\end{array}$ & $\begin{array}{c}\text { Group } \\
\text { SD }\end{array}$ \\
\hline Microalgae $50^{\circ} \mathrm{C}$ & $11.87 \%$ & $12.91 \%$ & $12.39 \%$ & $12.39 \%$ & $0.52 \%$ & & \\
\hline Microalgae $60^{\circ} \mathrm{C}$ & $12.33 \%$ & $12.39 \%$ & $11.76 \%$ & $12.16 \%$ & $0.35 \%$ & $12.18 \%$ & $0.41 \%$ \\
\hline Microalgae $70^{\circ} \mathrm{C}$ & $11.61 \%$ & $11.94 \%$ & $12.43 \%$ & $11.99 \%$ & $0.42 \%$ & & \\
\hline \multicolumn{8}{|l|}{ Oedogonium } \\
\hline Intact $50^{\circ} \mathrm{C}$ & $8.92 \%$ & $8.64 \%$ & $8.39 \%$ & $8.65 \%$ & $0.26 \%$ & & \\
\hline Intact $60^{\circ} \mathrm{C}$ & $9.19 \%$ & $10.93 \%$ & $10.94 \%$ & $10.35 \%$ & $1.01 \%$ & $9.13 \%$ & $1.06 \%$ \\
\hline Intact $70^{\circ} \mathrm{C}$ & $8.28 \%$ & $8.32 \%$ & $8.59 \%$ & $8.40 \%$ & $0.17 \%$ & & \\
\hline Fractured $50^{\circ} \mathrm{C}$ & $7.78 \%$ & $8.19 \%$ & $8.19 \%$ & $8.06 \%$ & $0.24 \%$ & & \\
\hline Fractured $60^{\circ} \mathrm{C}$ & $8.29 \%$ & $8.76 \%$ & $9.14 \%$ & $8.73 \%$ & $0.43 \%$ & $8.21 \%$ & $0.51 \%$ \\
\hline Fractured $70^{\circ} \mathrm{C}$ & $7.38 \%$ & $7.97 \%$ & $8.18 \%$ & $7.84 \%$ & $0.42 \%$ & & \\
\hline Aggregated $50^{\circ} \mathrm{C}$ & $7.94 \%$ & $8.22 \%$ & $8.38 \%$ & $8.18 \%$ & $0.22 \%$ & & \\
\hline Aggregated $60^{\circ} \mathrm{C}$ & $8.41 \%$ & $8.47 \%$ & $8.74 \%$ & $8.54 \%$ & $0.18 \%$ & $8.12 \%$ & $0.42 \%$ \\
\hline Aggregated $70^{\circ} \mathrm{C}$ & $7.57 \%$ & $7.59 \%$ & $7.79 \%$ & $7.65 \%$ & $0.12 \%$ & & \\
\hline
\end{tabular}

\section{Drying Phases and Total Drying Time}

All algae groups dried in two phases. Drying initially occurred in a constant-rate phase where the MR decreased at a constant rate until a threshold moisture level was reached. Then, the drying transitioned to a falling-rate phase where dehydration occurred at a progressively slower rate before finally reaching an equilibrium moisture content $(\mathrm{MR}=0)$. Each phase was identified based on its MR rate changes and the total time spent in each phase was recorded, as well as the total average drying time, as shown in Table 2. Minor differences were seen between the sample groups in the constant-rate phase, but the most significant differences in drying behavior were observed in the falling-rate phase. 
Table 2. Average Time Spent in Drying Phases and Total Average Drying Time.

\begin{tabular}{clccc}
\hline $\begin{array}{c}\text { Temperature } \\
\left({ }^{\circ} \mathrm{C}\right)\end{array}$ & Algae Group & $\begin{array}{c}\text { Constant-Rate } \\
\text { Phase } \\
(\mathrm{min})\end{array}$ & $\begin{array}{c}\text { Falling-Rate } \\
\text { Phase } \\
(\mathrm{min})\end{array}$ & $\begin{array}{c}\text { Total Drying } \\
\text { Time } \\
(\mathrm{min})\end{array}$ \\
\hline 50 & Microalgae & $0-150$ & $150-300(150 \mathrm{~min})$ & 300 \\
& Intact Oedogonium & $0-165$ & $165-255(90 \mathrm{~min})$ & 255 \\
& Fractured Oedogonium & $0-165$ & $165-210(45 \mathrm{~min})$ & 210 \\
& Aggregated Oedogonium & $0-150$ & $150-285(135 \mathrm{~min})$ & 285 \\
\hline \multirow{2}{*}{60} & Microalgae & $0-105$ & $105-180(75 \mathrm{~min})$ & 180 \\
& Intact Oedogonium & $0-105$ & $105-165(60 \mathrm{~min})$ & 165 \\
& Fractured Oedogonium & $0-105$ & $105-150(45 \mathrm{~min})$ & 150 \\
& Aggregated Oedogonium & $0-120$ & $120-195(75 \mathrm{~min})$ & 195 \\
\hline 70 & Microalgae & $0-75$ & $75-135(60 \mathrm{~min})$ & 135 \\
& Intact Oedogonium & $0-75$ & $75-120(45 \mathrm{~min})$ & 120 \\
& Fractured Oedogonium & $0-75$ & $75-120(45 \mathrm{~min})$ & 120 \\
& Aggregated Oedogonium & $0-75$ & $75-135(60 \mathrm{~min})$ & 135 \\
\hline
\end{tabular}

Note: Measurements taken every 15 min. A sample was categorized as dry once it was within $1 \%$ of its equilibrium moisture ratio.

\section{Comparative Drying of Microalgae and Intact Oedogonium}

As seen in Table 2, the intact Oedogonium samples dried faster than the microalgae at all temperatures. On average, intact Oedogonium dried 15\%, 8.3\%, and 11\% faster than microalgae at $50^{\circ} \mathrm{C}, 60^{\circ} \mathrm{C}$, and $70^{\circ} \mathrm{C}$, respectively. During the constant-rate phase, the microalgae and intact Oedogonium dried at similar rates (Table 3). However, the falling-rate phase was significantly shorter for the intact Oedogonium than for the microalgae (Table 2). Figure 3 shows the MR values of the intact Oedogonium and the microalgae during the falling-rate phase and illustrates how the drying rate of the microalgae initially decreased more quickly than that of intact Oedogonium but then plateaued at a lower rate. Thus, the microalgae dried slowly for an extended period and had a longer total drying time. 
Table 3. Average Constant-Phase Drying Rates.

\begin{tabular}{ccccc}
\hline $\begin{array}{c}\text { Temperature } \\
\left({ }^{\circ} \mathrm{C}\right)\end{array}$ & $\begin{array}{c}\text { Microalgae } \\
(-\mathrm{MR} / \mathrm{min})\end{array}$ & $\begin{array}{c}\text { Intact Oedogonium } \\
(-\mathrm{MR} / \mathrm{min})\end{array}$ & $\begin{array}{c}\text { Fractured Oedogonium } \\
(-\mathrm{MR} / \mathrm{min})\end{array}$ & $\begin{array}{c}\text { Aggregated Oedogonium } \\
(-\mathrm{MR} / \mathrm{min})\end{array}$ \\
\hline $50(0-150 \mathrm{~min})$ & $0.00527 \pm 0.00065$ & $0.00498 \pm 0.00068$ & $0.00562 \pm 0.00104$ & $0.00527 \pm 0.00108$ \\
$60(0-105 \mathrm{~min})$ & $0.00683 \pm 0.00082$ & $0.00746 \pm 0.00083$ & $0.00768 \pm 0.00081$ & $0.00640 \pm 0.00101$ \\
$70(0-75 \mathrm{~min})$ & $0.01078 \pm 0.00172$ & $0.01071 \pm 0.00183$ & $0.01033 \pm 0.00140$ & $0.01009 \pm 0.00138$ \\
\hline
\end{tabular}

Note: Drying rate $=$ decreasing moisture rate per minute $(-\mathrm{MR} / \mathrm{min})$.

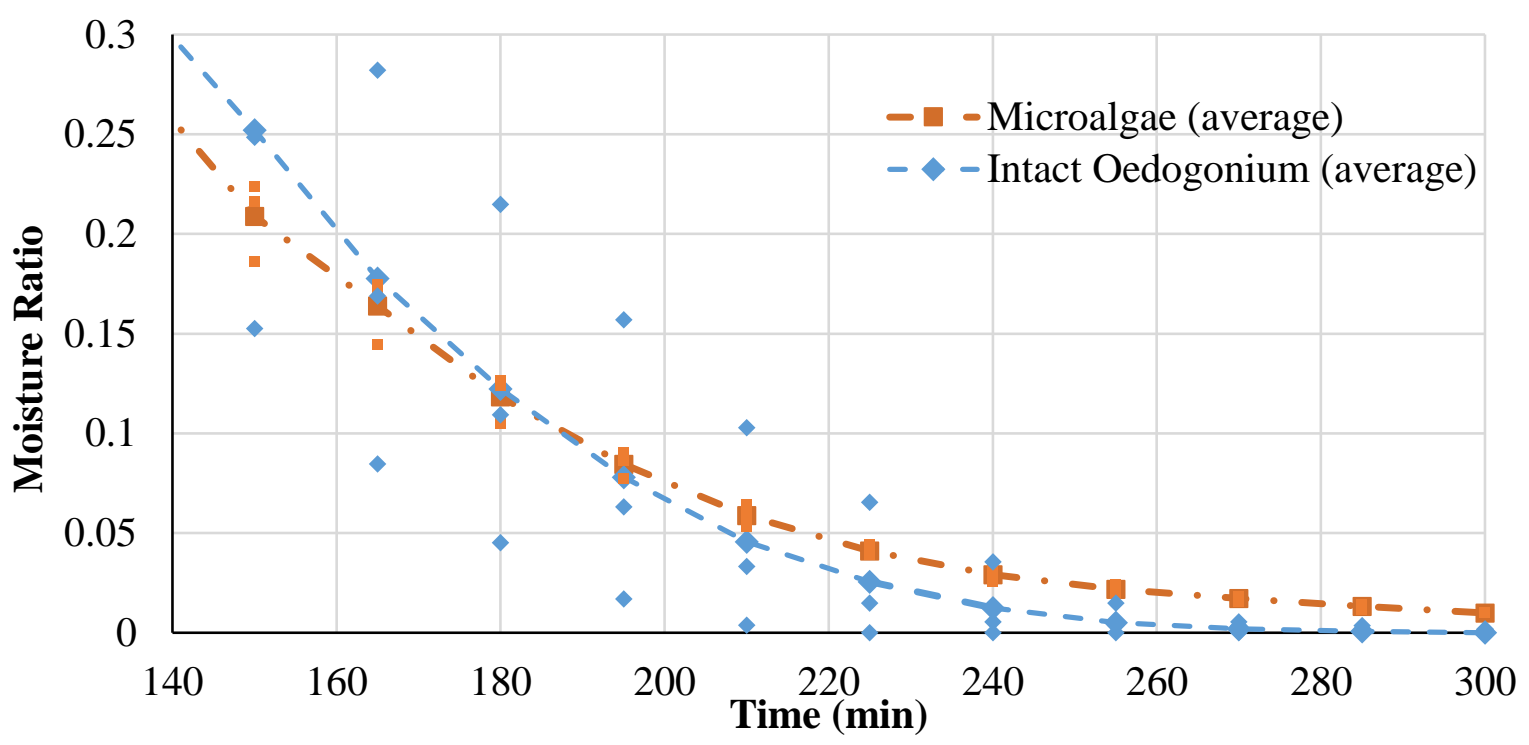

Figure 3. Average Moisture Ratio Trend and Measured Data Points of Microalgae and Intact Oedogonium during the Falling-Rate Phase at $50{ }^{\circ} \mathrm{C}$.

\section{Optimized Drying of Oedogonium Sample Groups}

Compared to intact Oedogonium, the fractured samples, on average, had a shorter total drying time at $50^{\circ} \mathrm{C}$ and $60^{\circ} \mathrm{C}$, but dried at a similar rate at $70^{\circ} \mathrm{C}$ (Table 2). At $50^{\circ} \mathrm{C}$, both the intact and fractured samples remained in the constant-rate phase for the first 165 minutes of drying. However, the fractured filaments had a significantly shorter falling-rate period before reaching their equilibrium moisture level. As seen in Table 2, the fractured samples, on average, spent only 45 minutes in the falling-rate phase at $50^{\circ} \mathrm{C}$ while the intact Oedogonium spent 90 minutes. Figure 4 shows how the MR of fractured samples dropped much faster than for intact samples. Similar behavior was seen at $60^{\circ} \mathrm{C}$, but, unlike other sample groups, the falling-rate period for the fractured Oedogonium did not decrease at higher temperatures. Consequently, the difference in total drying time between intact and fractured samples decreased at higher 
temperatures: fractured samples on average dried $17.6 \%$ faster at $50^{\circ} \mathrm{C}, 9.1 \%$ faster at $60^{\circ} \mathrm{C}$, but equally fast at $70^{\circ} \mathrm{C}$. The temperature dependence of the fracturing treatment effect was also seen by using Excel to perform a multivariable linear regression analysis on the constant-rate period at each temperature. Table 4 shows that fractured filaments had a coefficient of $-0.0647 \mathrm{MR}$ at $50^{\circ} \mathrm{C}$, while the coefficient was significantly lower at $60^{\circ} \mathrm{C}$, and even positive at $70^{\circ} \mathrm{C}$.

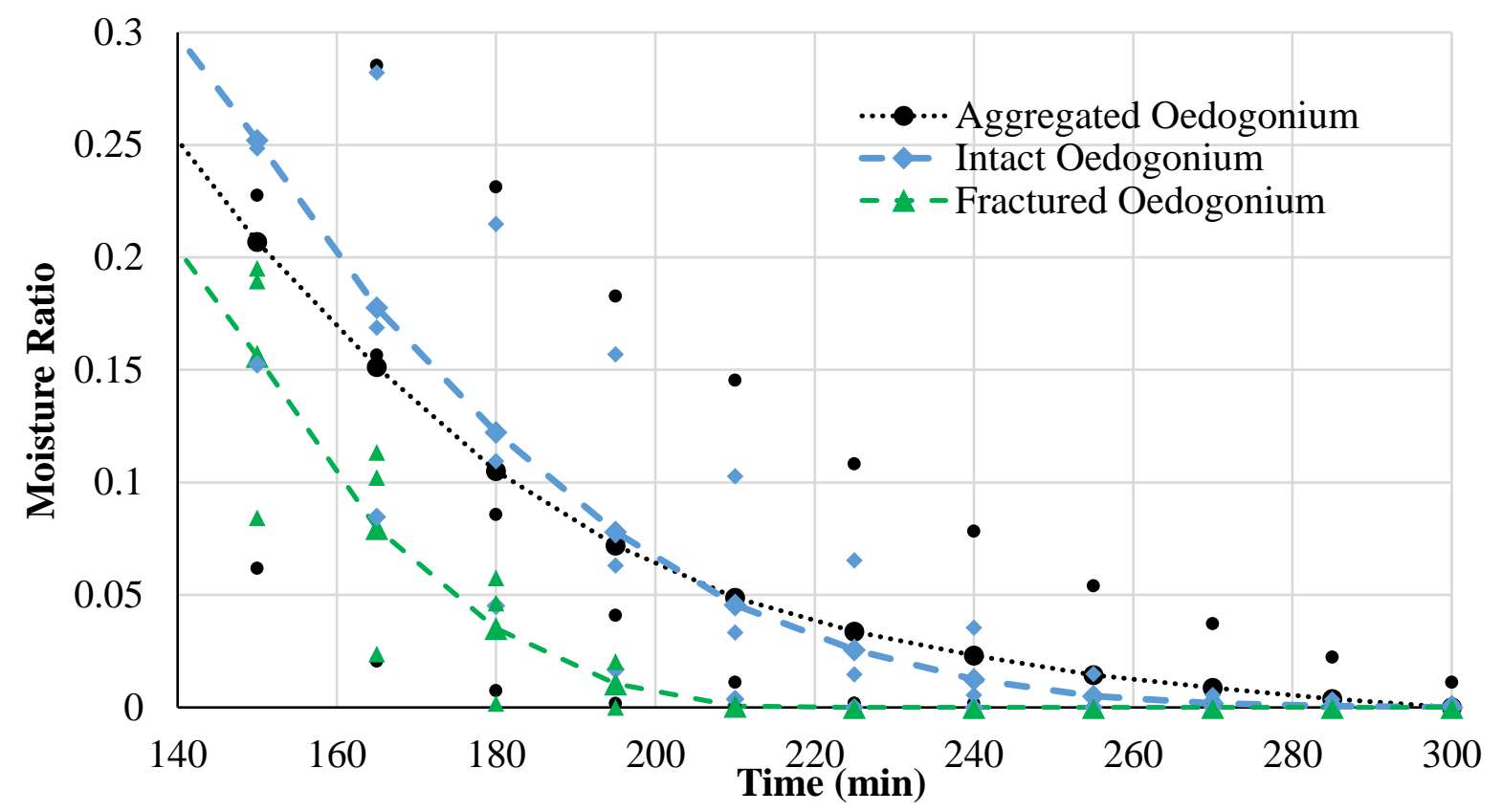

Figure 4. Average Moisture Ratio Trend and Measured Data Points of Oedogonium groups during the Falling-Rate Phase at $50{ }^{\circ} \mathrm{C}$.

Table 4. Linear Regression Fracturing Treatment Coefficients.

\begin{tabular}{cc}
\hline Temperature $\left({ }^{\circ} \mathrm{C}\right)$ & Treatment Effect $(\mathrm{MR})$ \\
\hline 50 & -0.06468 \\
60 & -0.01987 \\
70 & 0.01878 \\
\hline
\end{tabular}

The aggregated forms were found to dry slower than intact Oedogonium at all temperatures. Table 2 shows how the falling-rate phase of the aggregated forms was significantly longer than the other Oedogonium samples, and the flattening of the average MR curve after 210 minutes in Figure 4 illustrates how these samples experienced an extended period of slow drying, resulting in a longer total drying time. 


\section{Fick's Law Approximation}

The modeling approach successfully modeled falling-rate drying. Figures 5 and 6 illustrate the best fit (lowest RSS value) and worst fit (highest RSS value) of the model, respectively. The temperature dependence of the benefit of fracturing Oedogonium is also reflected by the $\mathrm{D}_{\mathrm{e}}$ values. As seen in Table 5, fractured Oedogonium had a higher $\mathrm{D}_{\mathrm{e}}$ than intact Oedogonium samples at $50^{\circ} \mathrm{C}$ and $60^{\circ} \mathrm{C}$ which in turn had a higher $\mathrm{D}_{\mathrm{e}}$ than the microalgae, while the $\mathrm{D}_{\mathrm{e}}$ of the aggregated forms had the lowest value of the Oedogonium groups at all temperatures. At $50^{\circ} \mathrm{C}$, the $\mathrm{D}_{\mathrm{e}}$ of the fractured samples is $126 \%$ higher than intact Oedogonium samples, but at $60^{\circ} \mathrm{C}$ the $\mathrm{D}_{\mathrm{e}}$ is only $25.5 \%$ higher, and at $70^{\circ} \mathrm{C}$ the $\mathrm{D}_{\mathrm{e}}$ is $9.1 \%$ lower.

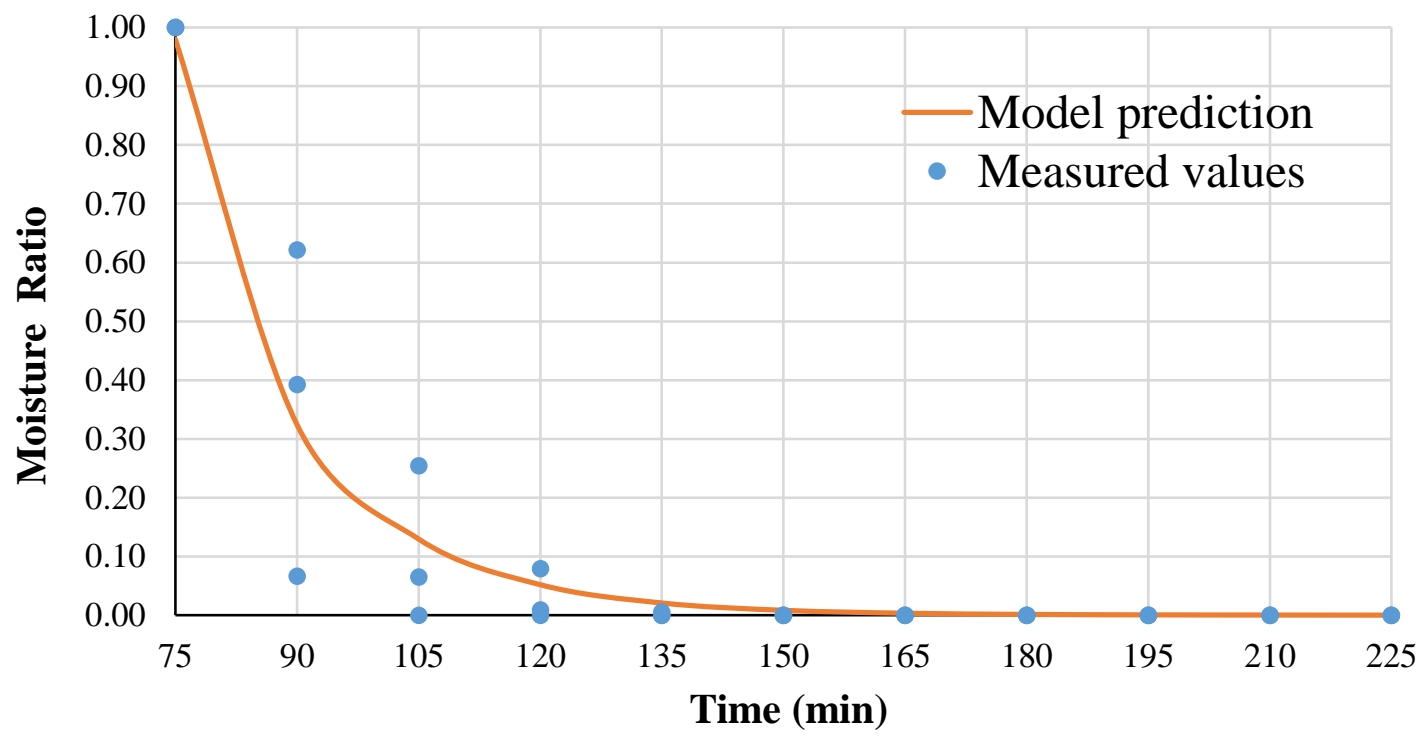

Figure 5. Best Fit Model of the Falling-Rate Moisture Ratio: Intact Oedogonium at $70^{\circ} \mathrm{C}$. 


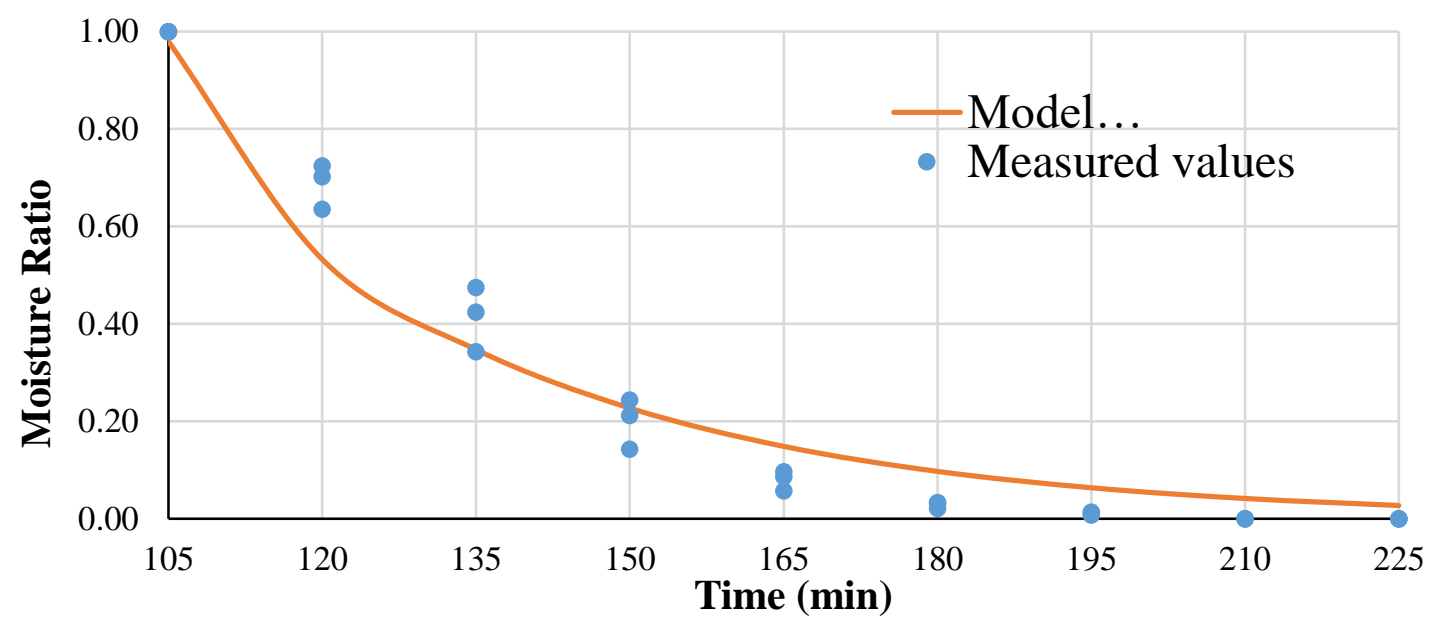

Figure 6. Worst Fit Model of the Falling-Rate Moisture Ratio: Microalgae at $60^{\circ} \mathrm{C}$.

Table 5. Effective Diffusivity and Residual Sum of Squares from Modeling.

\begin{tabular}{clcccc}
\hline Temperature & \multicolumn{1}{c}{ Measurement } & Microalgae & $\begin{array}{c}\text { Intact } \\
\text { Oedogonium }\end{array}$ & $\begin{array}{c}\text { Fractured } \\
\text { Oedogonium }\end{array}$ & $\begin{array}{c}\text { Aggregated } \\
\text { Oedogonium }\end{array}$ \\
\hline \multirow{2}{*}{$50^{\circ} \mathrm{C}$} & Effective Diffusivity $\left(\mathrm{m}^{2} / \mathrm{s}\right)$ & $4.48 \mathrm{E}-10$ & $7.71 \mathrm{E}-10$ & $1.74 \mathrm{E}-09$ & $6.71 \mathrm{E}-10$ \\
& Residual Sum of Squares & 0.0329 & 0.0218 & 0.0042 & 0.0050 \\
\hline \multirow{2}{*}{$60^{\circ} \mathrm{C}$} & Effective Diffusivity $\left(\mathrm{m}^{2} / \mathrm{s}\right)$ & $7.64 \mathrm{E}-10$ & $1.10 \mathrm{E}-09$ & $1.38 \mathrm{E}-09$ & $7.81 \mathrm{E}-10$ \\
& Residual Sum of Squares & 0.0443 & 0.0217 & 0.0166 & 0.0364 \\
\hline \multirow{2}{*}{$70^{\circ} \mathrm{C}$} & Effective Diffusivity $\left(\mathrm{m}^{2} / \mathrm{s}\right)$ & $1.15 \mathrm{E}-09$ & $1.65 \mathrm{E}-09$ & $1.50 \mathrm{E}-09$ & $1.09 \mathrm{E}-09$ \\
& Residual Sum of Squares & 0.0085 & 0.0032 & 0.0149 & 0.0176 \\
\hline
\end{tabular}

\section{Discussion}

The higher initial TS content of the microalgae, as seen in Table 1, and the corresponding lower initial moisture content should have caused the microalgae to dry faster than the intact Oedogonium. However, the results showed that drying microalgae was slower than drying intact Oedogonium. Therefore, if Oedogonium and microalgae had equal initial moisture contents, Oedogonium drying would be even more efficient than microalgae drying.

This study found that Oedogonium and microalgae followed the multi-phase drying patterns observed in thin-layer drying of fruit and vegetables (Onwude et al., 2016). More efficient dewatering could potentially be used to bypass the constant drying-rate phase. By using a centrifuge to dewater Oedogonium, Walker et al. (2020) were able to remove all surface moisture and cause all drying to occur in the falling-rate phase. Since Oedogonium showed its most 
significant advantage in this phase, more effective dewatering could further increase its drying efficiency in comparison to microalgae. However, centrifugation significantly increases the energy consumption of the drying process (Show et al., 2013). Further studies on low-energy dewatering methods would therefore be a key component in optimizing the energy efficiency of Oedogonium drying.

While this study suggests that a pre-drying fracturing treatment increases effective diffusivity and reduces the total drying time of Oedogonium at lower temperatures, Hammond et al. (2018) found that their pretreatment did not significantly affect drying. However, their cutting and tearing treatments only changed their Oedogonium samples on a macroscopic scale. In contrast, the treatment in this study fractured the filaments on a microscopic level, thus altering the material properties of the Oedogonium and resulting in faster drying. A fracturing treatment of Oedogonium could therefore prove to be beneficial for optimizing lower temperature drying methods such as solar drying.

Deformation during drying is considered a contributing factor to drying rates (Onwude et al., 2016) and could explain why fractured Oedogonium samples dried faster than intact samples. The fractured filaments developed cracks and broke into multiple pieces while the intact samples contracted to form one solid sheet, as seen in Figure 7. The formation of multiple pieces increased the total surface area and exposed internal regions of the blended samples, allowing moisture which otherwise would remain enclosed in the Oedogonium samples to more effectively migrate to the surface for evaporation, thereby increasing the drying rate.

Finally, for future research, it would be relevant to investigate if the fracturing treatment could also be used to increase the drying efficiency of aggregated forms of Oedogonium. Aggregated forms are simply entangled Oedogonium filaments, and it is reasonable to assume that the fracturing treatment would break this structure and result in a drying behavior similar to that of non-aggregated fractured Oedogonium. However, more research is needed to confirm this. 


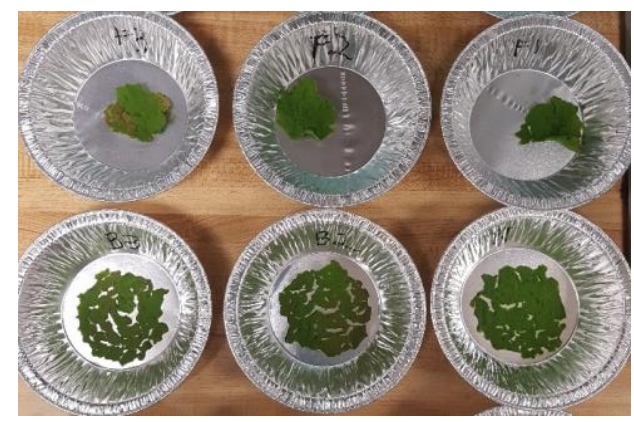

Figure 7. Dried Samples of Intact Oedogonium (top) and Fractured Oedogonium (bottom).

\section{Conclusion}

Drying of the filamentous algae Oedogonium was faster than drying of microalgae and, at lower temperatures, the drying efficiency of Oedogonium was further improved by a fracturing treatment. Since microalgae require complicated and often costly harvesting processes, filamentous algae such as Oedogonium already have a desirable advantage in terms of ease of harvesting. Its higher drying efficiency further supports the use of Oedogonium for algal biomass applications. Fracturing the Oedogonium filaments increases their effective diffusivity at lower temperatures and thus gives fractured samples a considerable advantage during the falling-rate phase of drying. This treatment should, therefore, be considered for the optimization of lower temperature drying methods such as solar drying. Although aggregated forms dried slower than intact Oedogonium, their additional ease of harvesting is a potential benefit. If a fracturing treatment was used to increase their drying efficiency, cultivation of aggregated forms of Oedogonium could also be considered for optimization of the algae production process.

\section{Acknowledgements}

This research was conducted as part of the 2019-20 CALS University Scholars Program and SWS 4911: Supervised Research in Soil and Water Sciences, at the Bioenergy and Sustainable Technology Laboratory, Soil and Water Sciences Department, UF/IFAS.

\section{References}

Akpinar, E. K. (2006). Determination of suitable thin layer drying curve model for some vegetables and fruits. Journal of Food Engineering, 73(1), 75-84. doi:10.1016/j.jfoodeng.2005.01.007

APHA (2012). Standard Methods for the Examination of Water and Wastewater, $22^{\text {nd }}$ ed. American Public Health Association / American Water Works Association / Water Environment Federation, Washington, DC. 
Cole, A. J., Mata, L., Paul, N. A., \& de Nys, R. (2014). Using $\mathrm{CO}_{2}$ to enhance carbon capture and biomass applications of freshwater macroalgae. GCB Bioenergy, 6(6), 637-645.

doi:10.1111/gcbb.12097

Cole, A. J., Neveux, N., Whelan, A., Morton, J., Vis, M., de Nys, R., \& Paul, N. A. (2016). Adding value to the treatment of municipal wastewater through the intensive production of freshwater macroalgae. Algal Research, 20, 100-109. doi:10.1016/j.algal.2016.09.026

Edmundson, S. J., \& Wilkie, A. C. (2013). Landfill leachate - a water and nutrient resource for algaebased biofuels. Environmental Technology, 34(13-14), 1849-1857. doi: $\underline{10.1080 / 09593330.2013 .826256}$

Grayburn, W. S., Tatara, R. S., Rosentrater, K. A., \& Holbrook, G. P. (2013). Harvesting, oil extraction, and conversion of local filamentous algae growing in wastewater into biodiesel. International Journal of Energy \& Environment, 4(2), 185-190. http://www.ijee.ieefoundation.org/vol4/issue2/IJEE 02 v4n2.pdf

Gudin, C., \& Thepenier, C. (1986). Bioconversion of solar energy into organic chemicals by microalgae. In: Mizrahi, A. (Ed.), Advances in Biotechnological Processes, Vol. 6. p.73-110. New York: Alan R. Liss.

Guiné, R. P. F., Pinho, S., \& Barroca, M. J. (2011). Study of the convective drying of pumpkin (Cucurbita maxima). Food and Bioproducts Processing, 89(4), 422-428. doi:10.1016/j.fbp.2010.09.001

Hammond, L., Bai, L., Sheehan, M., \& Walker, C. (2018). Experimental analysis and diffusion modelling of solar drying of macroalgae - Oedogonium sp. Chemical Engineering Transactions, 65, 427432. doi: $10.3303 / \mathrm{CET} 1865072$

Kraan, S. (2013). Mass-cultivation of carbohydrate rich macroalgae, a possible solution for sustainable biofuel production. Mitigation and Adaptation Strategies for Global Change, 18(1), 27-46. doi: 10.1007/s11027-010-9275-5

Lawton, R. J., de Nys, R., Skinner, S., \& Paul, N. A. (2014). Isolation and identification of Oedogonium species and strains for biomass applications. PLOS ONE, 9(3), e90223. doi: $\underline{10.1371 / \text { journal.pone.0090223 }}$

Lincoln, E. P., Wilkie, A. C., \& French, B. T. (1996). Cyanobacterial process for renovating dairy wastewater. Biomass and Bioenergy, 10(1), 63-68. doi:10.1016/0961-9534(95)00055-0

Molina Grima, E., Belarbi, E.-H., Acién Fernández, F. G., Robles Medina, A., \& Chisti, Y. (2003). Recovery of microalgal biomass and metabolites: process options and economics. Biotechnology Advances, 20(7-8), 491-515. doi:10.1016/S0734-9750(02)00050-2

O’Connell, R., \& Wilkie, A. C. (2018). Comparing harvest productivity of the filamentous alga Oedogonium with microalgae. UF Journal of Undergraduate Research, 20(1), 1-9. doi:10.32473/ufjur.v20i1.106221

Onwude, D. I., Hashim, N., Janius, R. B., Mat Nawi, N., \& Abdan, K. (2016). Modeling the thin-layer drying of fruits and vegetables: a review. Comprehensive Reviews in Food Science and Food Safety, 15(3), 599-618. doi:10.1111/1541-4337.12196

Piotrowski, M. J., Graham, L. E., \& Graham, J. M. (2020). Temperate-zone cultivation of Oedogonium in municipal wastewater effluent to produce cellulose and oxygen. Journal of Industrial Microbiology \& Biotechnology, 47(2), 251-262. doi:10.1007/s10295-020-02260-0 
Sherwood, T. K. (1932). The drying of solids-IV application of diffusion equations. Industrial \& Engineering Chemistry, 24(3), 307-310. doi:10.1021/ie50267a010

Show, K.-Y., Lee, D.-J., \& Chang, J.-S. (2013). Algal biomass dehydration. Bioresource Technology, 135, 720-729. doi:10.1016/j.biortech.2012.08.021

Spolaore, P., Joannis-Cassan, C., Duran, E., \& Isambert, A. (2006). Commercial applications of microalgae. Journal of Bioscience and Bioengineering, 101(2), 87-96. doi:10.1263/jbb.101.87

Walker, C., Cole, A., Antunes, E., \& Sheehan, M. (2020). Equilibrium moisture and drying kinetics modelling of macroalgae species Ulva ohnoi and Oedogonium intermedium. Clean Technologies, 2(2), 225-239. doi:10.3390/cleantechnol2020015

Wilkie, A. C. (2008). Biomethane from biomass, biowaste, and biofuels. In: Wall, J., Harwood, C., \& Demain, A. (Eds.), Bioenergy, p.195-205. Washington, DC: ASM Press. doi:10.1128/9781555815547.ch16

Wilkie, A. C., Edmundson, S. J., \& Duncan, J. G. (2011). Indigenous algae for local bioresource production: Phycoprospecting. Energy for Sustainable Development, 15(4), 365-371. doi:10.1016/j.esd.2011.07.010

Wilkie, A. C., \& Mulbry, W. W. (2002). Recovery of dairy manure nutrients by benthic freshwater algae. Bioresource Technology, 84(1), 81-91. doi:10.1016/S0960-8524(02)00003-2

Zhang, W., Zhao, Y., Cui, B., Wang, H., \& Liu, T. (2016). Evaluation of filamentous green algae as feedstocks for biofuel production. Bioresource Technology, 220, 407-413. doi:10.1016/j.biortech.2016.08.106 